\title{
Cochlear implantation in elderly: indication and results
}

\author{
R Filipo*, D Ballantyne, C D'Elia, P Mancini \\ From de Senectute: Age and Health Forum \\ Catanzaro, Italy. 5-7 December 2009
}

\section{Background}

There is a growing interest by clinical researchers on quality of life and outcomes of cochlear implant patients, particularly considering the extension of indication to the more elderly. This is especially related to the cost-benefit issues in patients were the benefit might be reduced by aging of the auditory system which is a more central process, together with general health problems which might be affected by any surgical procedure. Vermeire ${ }^{1}$ and coauthors have reported that although there is no difference between self-reported measure of benefit between patients implanted younger or older than 70 years, still 70-and-over had lower speech performance then younger participants. The aim of the study was to investigate the outcome of CI among elderly cochlear implant recipients.

\section{Materials and methods}

A total of 29 post-lingual adults implanted with Clarion ${ }^{\circ}$ 1.2, $\mathrm{CII}$ and $\mathrm{HiRes}^{\circ} 90 \mathrm{~K}$ were selected for trials. Group
1 consisted of 9 patients with mean age at implant 76.2 yrs Group 2 consisted of 20 patients with mean age at implant 59.1 yrs. All patients were tested (open-set mode) with bisyllabic words and sentences, in both quiet and noise [speech/noise ratio (SNR) $=+10$ and 5]. Statistical analysis of results was carried out with the student T-test. Testing was carried out after a minimum of 9 moths of cochlear implant use.

\section{Results}

Result for speech perception in quiet and in noise showed a tendency for better results in subjects 50-60 years old, nevertheless differences were not statistically significant. Figure 1

\section{Conclusions}

Results from our study have shown that elder patient implanted above 75 yrs can obtain significant hearing benefit from cochlear implantation. Similarly to the
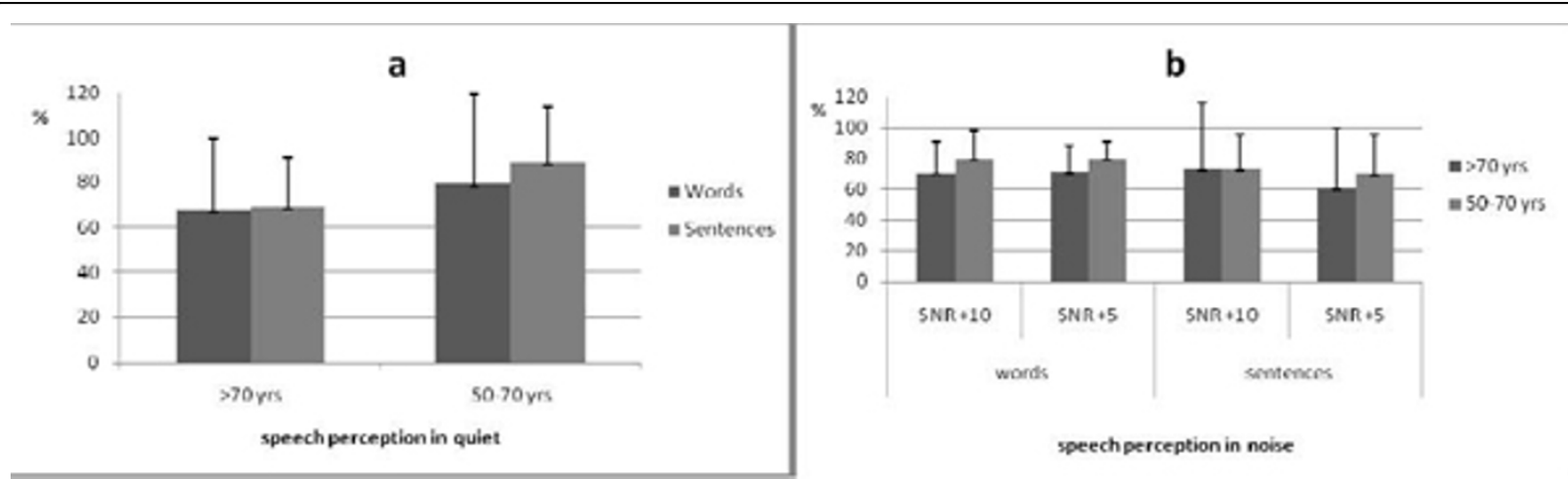

Figure 1 1a: speech perception in quiet for bysillabic words and sentences. 1b: speech perception in noise with SNR +10 and 5, for bysillabic words and sentences.

Department of Neurology and Otolaryngology, University "La Sapienza" of Rome, Italy 
results reported by Vermeer ${ }^{1}$, in our study subjects implanted at elder age show lower scores compared to younger adult implantees. Nevertheless differences are not statistically significant, and, more important, the overall results are excellent even though elders require more counseling and attention. Furthermore activities connected to rehabilitation, often required to improve implant use, become inherently an input which favors the patient's interest and motivation towards everyday life.

Published: 19 May 2010

\section{Reference}

1. Vermeire K, Brokx JP, Wuyts FL, Cochet E, Hofkens A, Van de Heyning PH: Quality-of-life benefit from cochlear implantation in the elderly. Otol Neurotol. 2005, 26(2):188-195.

doi:10.1186/1471-2318-10-S1-A107

Cite this article as: Filipo et al: Cochlear implantation in elderly: indication and results. BMC Geriatrics 2010 10(Suppl 1):A107.
Submit your next manuscript to BioMed Central and take full advantage of:

- Convenient online submission

- Thorough peer review

- No space constraints or color figure charges

- Immediate publication on acceptance

- Inclusion in PubMed, CAS, Scopus and Google Scholar

- Research which is freely available for redistribution

Submit your manuscript at www.biomedcentral.com/submit 